\title{
The dopamine receptor D4 regulates the proliferation of pulmonary arteries smooth muscle in broilers by downregulating AT1R
}

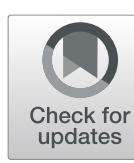

Xiaoqi Yang ${ }^{1}$, Yang Fu', Lianfeng $\mathrm{Wu}^{1}$, Antong Li', Luyao Ji', Hao Li', Yuxuan Peng ${ }^{1}$, Jiabin Zhang ${ }^{1}$, Donghai Zhou ${ }^{1^{*}}$ (D) and Huiping Zhou ${ }^{2^{*}}$

\begin{abstract}
The major cause of pulmonary vascular remodeling in broilers is abnormal proliferation of vascular smooth muscle cells (VSMCs), and one of the main causes of pulmonary hypertension syndrome (PHS) in broilers is pulmonary artery vascular remodeling. Forty Arbor Acres (AA) broilers were randomly divided into four groups $(n=10)$ : a control group (deionized water, $0 \mathrm{~g} / \mathrm{L} \mathrm{NaCl}$ ), a freshwater group (FW, deionized water $+1 \mathrm{~g} / \mathrm{L} \mathrm{NaCl}$ ), highly salinized freshwater group 1 (H-SFW-1, deionized water $+2.5 \mathrm{~g} / \mathrm{L} \mathrm{NaCl}$ ) and highly salinized freshwater group 2 ( $\mathrm{H}-\mathrm{SFW}-2$, deionized water $+5 \mathrm{~g} / \mathrm{L} \mathrm{NaCl}$ ). The results of in vivo experiments showed that vascular smooth muscle of the broilers could be significantly proliferated by intake of high-salinity fresh water (H-SFW-1 \& H-SFW-2), which significantly increased the content of angiotensin II (Ang II) and the expression of angiotensin II type 1 (AT1) receptor protein. Meanwhile, it significantly decreased the expression of dopamine receptor D4 (DRD4) protein. The results of in vitro experiments showed that exogenous Ang II induced the proliferation of primary VSMCs in broilers, which could be significantly inhibited by DRD4 agonists (D4A, HY-101384A) and enhanced by DRD4 inhibitors (D4I, HY-B0965). In addition, the results of immunoblotting and fluorescence quantitative PCR showed that AT1 receptors could be negatively regulated by DRD4 in VSMCs of broilers, either at the transcriptional or translational level. At the same time, the expression of AT1 receptor could be increased by DRD4 inhibition by D4I and decreased by DRD4 activation by D4A. The negative regulatory effect of DRD4 on AT1 receptor occurred in a dose-dependent manner. These results indicate that long-term intake of highly salinized fresh water can cause PHS in broilers, accompanied by varying degrees of proliferation of pulmonary artery smooth muscle. This mechanism may involve response of its receptor being induced by increased Ang II, while DRD4 can negatively regulate it.
\end{abstract}

Keywords: AT1 receptors, Dopamine receptor D4, PHS, Vascular smooth muscle, Angiotensin II

\section{Introduction}

In China's saltwater lake regions (Mengxin Lake District and Qinghai-Tibet Plateau Lake District) and the southeast coastal areas, salt content in

\footnotetext{
*Correspondence: bigdefoot@163.com; zhouhuiping0925@163.com 'Veterinary Clinical Medicine Laboratory, College of Veterinary Medicine, Huazhong Agricultural University, Shizishan Street, Wuhan 430070, People's Republic of China

${ }^{2}$ School of Basic Medical, Hubei University of Science \& Technology, Xianning 437100, People's Republic of China
}

environmental water bodies is typically higher than $0.1 \%$, above the international freshwater standard. Meanwhile, water medium in coastal areas is salinized because the seawater is isolated, thus forming salt lakes with higher salt contents. Due to incorrect usage and discharge of industrial water (agriculture and domestic), the chemical composition of fresh water in some areas has gradually changed, resulting in a variety of ecological pressures and eventually in freshwater salinization. Excessive intake of sodium chloride can

(c) The Author(s). 2021, corrected publication 2022. Open Access This article is licensed under a Creative Commons Attribution 4.0 International License, which permits use, sharing, adaptation, distribution and reproduction in any medium or format, as long as you give appropriate credit to the original author(s) and the source, provide a link to the Creative Commons licence, and indicate if changes were made. The images or other third party material in this article are included in the article's Creative Commons licence, unless indicated otherwise in a credit line to the material. If material is not included in the article's Creative Commons licence and your intended use is not permitted by statutory regulation or exceeds the permitted use, you will need to obtain permission directly from the copyright holder. To view a copy of this licence, visit http://creativecommons.org/ licenses/by/4.0/. The Creative Commons Public Domain Dedication waiver (http://creativecommons.org/publicdomain/zero/1. 0/) applies to the data made available in this article, unless otherwise stated in a credit line to the data. 
induce animal diseases. For broilers, $\mathrm{Na}^{+}$at the same concentration is more toxic in drinking water than in feed (Julian et al. 1992). Studies have shown that longterm consumption of highly salinized freshwater by broilers can cause pulmonary hypertension syndrome (PHS) (Mirsalimi et al. 1993; Zhang et al. 2013), which has a significant impact on the broiler breeding industry.

One of the major pathological causes of PHS in broilers is pulmonary vascular remodeling. Its main pathological changes are abnormal hypertrophy and proliferation of smooth muscle cells, which leads to thickening of pulmonary artery wall and stenosis of lumen and finally to pulmonary hypertension. It has been confirmed that pulmonary hypertension in broilers will eventually lead to ascites (Julian 1993; Wideman Jr. and Kirby 1995). Therefore, a key entry point to prevent and treat PHS is to inhibit or alleviate the abnormal proliferation of broiler vascular smooth muscle cells (VSMCs).

Studies have shown (Crossley 2nd et al. 2010; Hassanpour et al. 2019) that the renin-angiotensin system (RAS) is involved in the pathogenesis of pulmonary hypertension in broilers. Abnormal expression or activity of RAS is closely related to vascular remodeling and abnormal blood pressure. As an important factor in RAS, angiotensin II (Ang II) can cause vascular remodeling and hypertension by constricting blood vessels, affecting cell proliferation and migration, promoting extracellular matrix synthesis and inducing an inflammatory response (Ibrahim 2006; Luo et al. 2015).

In mammals, Ang II can stimulate the proliferation of VSMCs by promoting it's DNA synthesis (Touyz et al. 2004; Zheng et al. 2007), stimulating the expression of proto-oncogenes, such as c-jun, c-fos, and cmyc (Delaney et al. 2008; Reiss et al. 1993), promoting mitosis and secretion of growth factors, such as platelet derived growth factor (PDGF) (Wang et al. 2005). Previous studies have found that cloned angiotensin II type 1 (AT1)-homologous receptors (359 amino acid residues) in chicken adrenal glands have $75 \%$ amino acid homology with mammalian AT1 (Kempf et al. 1996). It has been shown that AT1 homologous receptor $(c A T 1)$ is expressed in vascular smooth muscle (VMS) of chorioallantoic artery, in the outer layer of adventitia, and in the aorta of chicken embryos. The expression of $c A T 1$ in smooth muscle (SM) layer of the external aorta was found to decrease after birth and was completely eliminated in adult chickens (Nishimura et al. 2003). We speculate that Ang II can affect the growth and proliferation of blood vessels through AT1 receptor, but whether this effect exists throughout the whole process of growth and development of broilers requires further study.
As an important neurotransmitter that functions through two classes of receptors (D1 and D2), dopamine affects a variety of biological processes in vertebrates. Studies have shown that serotonin may be involved in the occurrence of pulmonary artery remodeling in PHS broilers, and the mechanism by which serotonin regulates dopamine neurons is still under study (Ying et al. 2011). Dopamine receptors are classified into two types according to their structural and pharmacological properties, namely, dopamine receptor D1 (including D1 and D5) and dopamine receptor D2 (including D2, D3 and D4). In multiple mammalian studies, DRD4 (as an important component of $\mathrm{D} 2$ receptors) plays an important role in the pathogenesis of hypertension (Banday and Lokhandwala 2008; Harris and Zhang 2012; Horita et al. 2013; Zeng et al. 2008). Increasing evidence has confirmed that there was an interaction between DRD4 and AT1 receptor. The expression of renal AT1 receptor in D4 knockout mice was higher than that of wild-type mice of the same brood, and when high doses of AT1 receptor inhibitor were applied to these DRD4-deficient mice, the degree and duration of the antihypertensive effect of AT1 receptor was longer (Bek et al. 2006). Destruction of DRD4 gene can lead to hypertension associated with increased expression of renal AT1 receptor (Julian 1993). By downregulating the expression of insulin receptors and AT1 receptors, DRD4 can inhibit the proliferation and migration of VSMCs mediated by insulin or angiotensin II ( $\mathrm{Yu}$ et al. 2015; Yu et al. 2014). Previous scholars have cloned two D2-like dopamine receptors (cDRD2 and cDRD4) from chicken brains. The cloned cDRD4 is a 378-amino acid receptor with 57\% homology with mouse DRD4. Experiments have shown that cDRD4 is a functional receptor that is able to mediate the action of dopamine ( $\mathrm{Lv}$ et al. 2018). However, there are few studies on DRD4 in poultry, and whether they have the same regulatory effect on AT1 receptors is still unknown.

In summary, long-term intake of highly salinized fresh water is an important cause of PHS in broilers. The proliferation of pulmonary artery smooth muscle is a key factor in the formation of PHS, whose regulatory mechanism is worthy of in-depth research.

\section{Results}

\section{Effect of freshwater salinization on broilers}

Visual examination of the four groups of broilers was performed on the last day of the experiment. The results showed that there was little difference in appearance between FW (fresh water) group and control group. Broilers in both groups were glossy, vigorous and quick in response. On the other hand, broilers of H-SFW1 (high salinized freshwater group 1) group and H-SFW2 (high salinized freshwater group 2) group had rough 
coats, lacked energy, and were slow in response, with the situation of H-SFW-2 group being more serious. Broilers in H-SFW-2 group had abdominal swelling, and when touched, a sense of fluctuation was felt. Dissection showed a large amount of light-yellow jelly like ascites in the peritoneum. As showed in Fig. 1a and b, ascites heart index (AHI) and hematocrit (HCT) of H-SFW-1 and H-SFW-2 were significantly higher than those of control group $(P<0.01)$, while AHI and HCT of FW group were not significantly different from those of control group. Among broilers, $70 \%$ in $\mathrm{H}$ SFW-1 group and $100 \%$ in $\mathrm{H}-\mathrm{SFW}-2$ group had AHI that met the criteria for successful modeling, and 33\% in $\mathrm{H}-\mathrm{SFW}-1$ group and $80 \%$ in $\mathrm{H}-\mathrm{SFW}-2$ group had HCT that met these criteria. The results showed that $5 \mathrm{~g} / \mathrm{L} \mathrm{NaCl}$ was more likely to cause PHS than $2.5 \mathrm{~g} / \mathrm{L}$ $\mathrm{NaCl}$.

\section{Effects of freshwater salinization on the proliferation of pulmonary artery smooth muscle in broilers}

Because proliferating cell nuclear antigen (PCNA) exists only in normal proliferating cells and tumor cells, expression of PCNA in the four groups of broilers was detected by western blotting to reflect difference in the effect of various doses of salinized fresh water on the proliferation of pulmonary artery smooth muscles in broilers. As showed in Fig. 2a, expressions of PCNA protein in $\mathrm{H}-\mathrm{SFW}-1$ and $\mathrm{H}-\mathrm{SFW}-2$ groups were significantly higher than that in control group $(P<0.01)$, and expression of PCNA in H-SFW-2 group was significantly higher than that in $\mathrm{H}-\mathrm{SFW}-1$ group $(P<0.05)$. Meanwhile, no significant difference was seen between FW group and control group. This showed that drinking salinized fresh water containing different concentrations of $\mathrm{NaCl}$ for the same amount of time would cause different degrees of cell proliferation in VSM of broilers, which is the pathological basis for pulmonary vascular remodeling.
Effect of freshwater salinization on Ang II content in VSM of broilers

Figure 3 showed effects of different concentrations of salinized fresh water on Ang II content in VSM of broilers. Ang II contents of H-SFW-1 and H-SFW-2 groups were significantly higher $(P<0.01)$ than that of control group. Additionally, Ang II content in $\mathrm{H}$ SFW-2 group was significantly higher than that in $\mathrm{H}$ SFW-1 group $(P<0.01)$. These results indicated that intake of water containing different concentrations of $\mathrm{NaCl}$ under the same action time would increase Ang II content in VSM of broilers to varying degrees, which may cause the expression of Ang II downstream proteins to change correspondingly.

\section{Effects of freshwater salinization on AT1 receptor and DRD4 in VSM of broilers}

To study the effects of different concentrations of salinized freshwater inVSM of broilers, western blotting was used to detect the expression of AT1 receptor and DRD4 in the four groups. As showed in Fig. 2b and c, protein expression levels of AT1 receptor in in H-SFW-1 and H-SFW-2 groups were significantly higher than that in control group $(P<0.01)$, while protein expression level in DRD4 was significantly lower $(P<0.01)$. In addition, expression levels of AT1 receptor and DRD4 in FW group were not significantly different from those in control group. Such results showed that protein expression of AT1 receptor and DRD4 were positively correlated with the concentration of $\mathrm{NaCl}$ and that a certain negative regulatory effect existed between AT1 receptor and DRD4.

\section{Effect of Ang II on the proliferation of primary VSMCs in broilers}

Results of in vivo experiment showed that highly salinized freshwater could induce PHS in broilers, accompanied by the proliferation of pulmonary artery smooth muscle and an increased in Ang II. VSMCs from 18-day-old AA broiler embryos were successfully cultured and identified
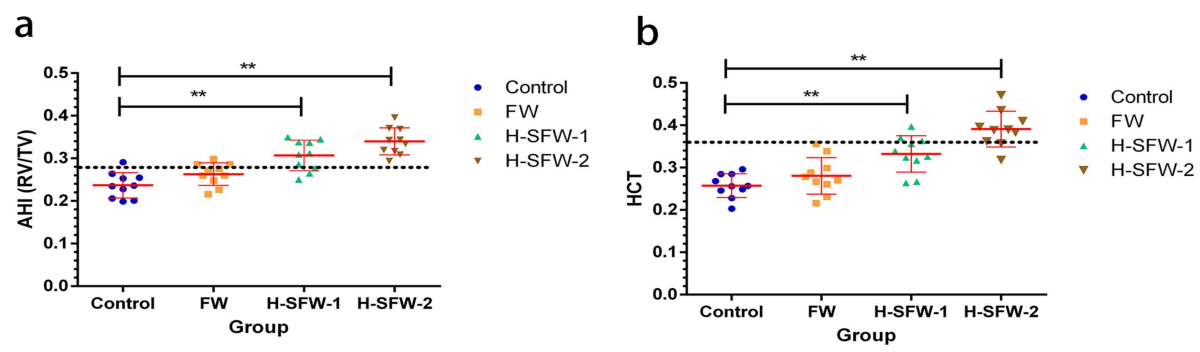

Fig. 1 Effects of different $\mathrm{NaCl}$ contents in drinking water on hematocrit $(\mathrm{HCT})$ and ascites heart index (AHI) of broilers. They were randomly divided into four groups: a control group (deionized water, $\mathrm{NaCl}$ at $0 \mathrm{~g} / \mathrm{L}$ ), a freshwater group (FW, deionized water $+\mathrm{NaCl}$ at $1 \mathrm{~g} / \mathrm{L}$ ), high salinized freshwater group 1 ( $\mathrm{H}-\mathrm{SFW}-1$, deionized water $+\mathrm{NaCl}$ at $2.5 \mathrm{~g} / \mathrm{L}$ ) and high salinized freshwater group $2(\mathrm{H}-\mathrm{SFW}-2$, deionized water $+\mathrm{NaCl}$ at $5 \mathrm{~g} / \mathrm{L})$. a AHI (RV/TV, right ventricular weight/total ventricular weight) of broilers in control group, FW group, H-SFW-1 group and H-SFW-2 group. ( $n=10$, ** $P<0.01$ vs. control). $\mathbf{b}$ HCT of broilers in control group, FW group, H-SFW-1 group and H-SFW-2 group $\left(n=10,{ }^{* *} P<0.01\right.$ vs. control) 

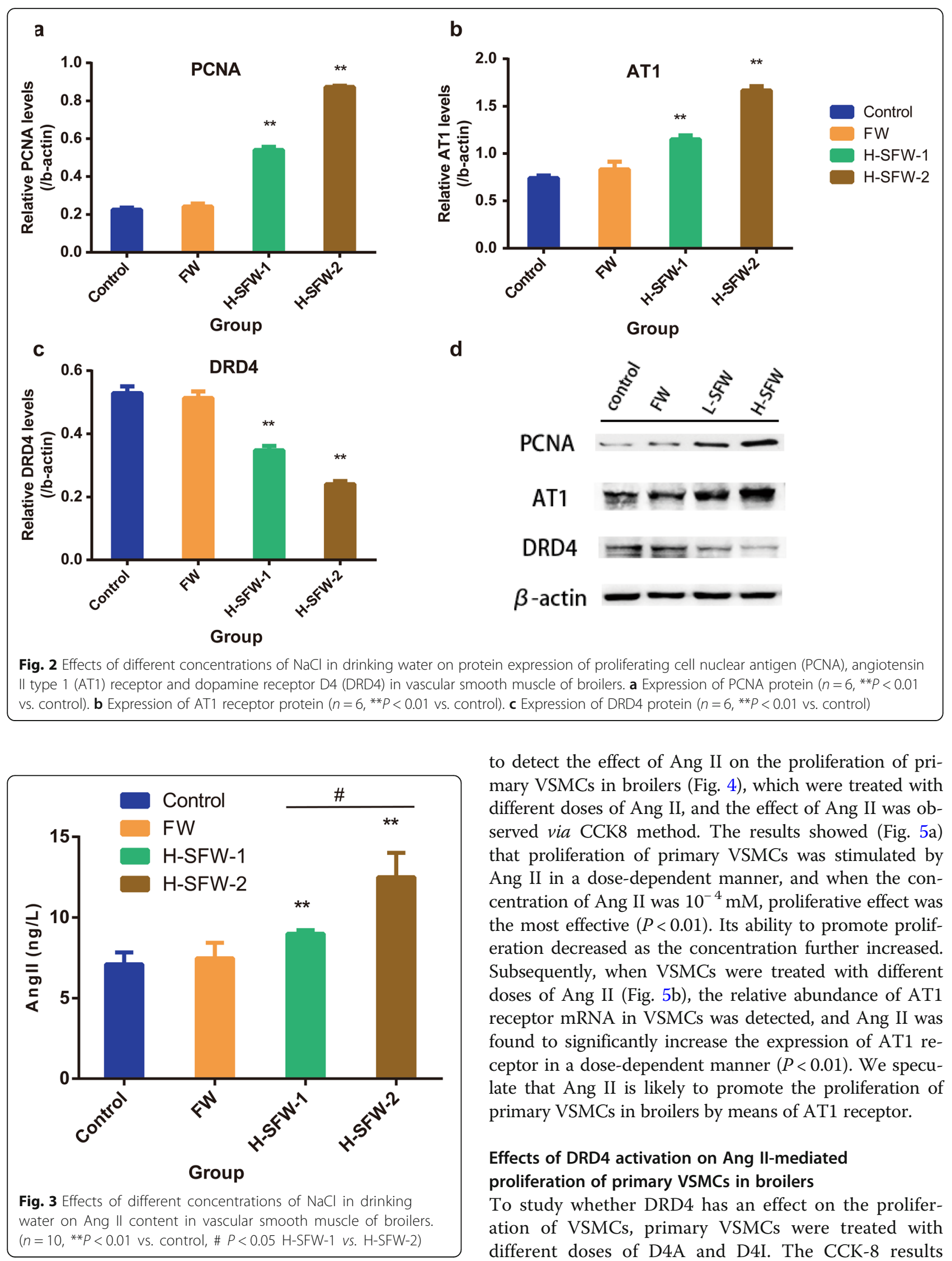

to detect the effect of Ang II on the proliferation of primary VSMCs in broilers (Fig. 4), which were treated with different doses of Ang II, and the effect of Ang II was observed via CCK8 method. The results showed (Fig. 5a) that proliferation of primary VSMCs was stimulated by Ang II in a dose-dependent manner, and when the concentration of Ang II was $10^{-4} \mathrm{mM}$, proliferative effect was the most effective $(P<0.01)$. Its ability to promote proliferation decreased as the concentration further increased. Subsequently, when VSMCs were treated with different doses of Ang II (Fig. 5b), the relative abundance of AT1 receptor mRNA in VSMCs was detected, and Ang II was found to significantly increase the expression of AT1 receptor in a dose-dependent manner $(P<0.01)$. We speculate that Ang II is likely to promote the proliferation of primary VSMCs in broilers by means of AT1 receptor.

\section{Effects of DRD4 activation on Ang II-mediated} proliferation of primary VSMCs in broilers

To study whether DRD4 has an effect on the proliferation of VSMCs, primary VSMCs were treated with different doses of D4A and D4I. The CCK-8 results 


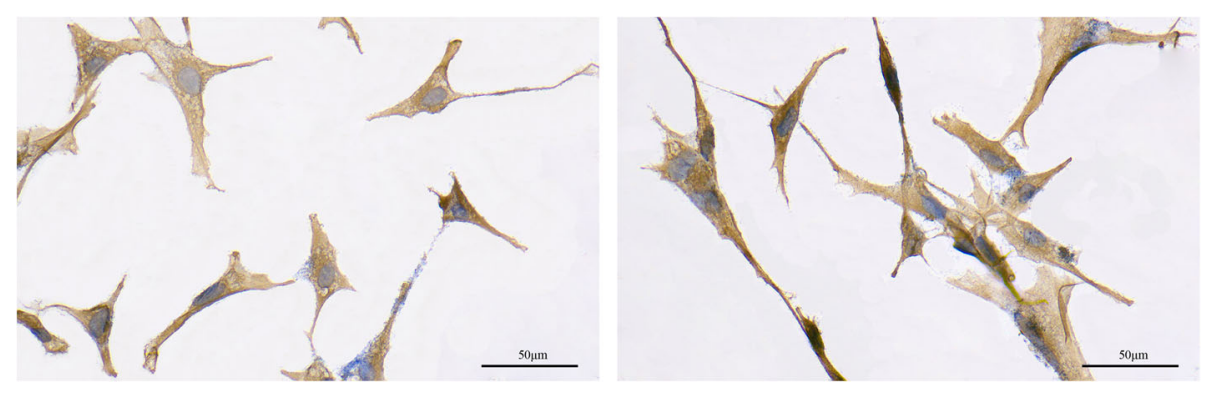

Fig. 4 Anti-alpha smooth muscle actin antibody identification of primary vascular smooth muscle cells (VSMCs) in broilers

showed that simply activating or inhibiting DRD4 had no significant effect (Fig. 6a, b). However, activation of DRD4 significantly inhibited $(P<0.01)$ abnormal proliferation of primary VSMCs mediated by Ang II in a dose-dependent manner (Fig. 6c). At the same time, inhibition of DRD4 significantly enhanced the proliferation of primary VSMCs induced by Ang II in a dose-dependent manner (Fig. 6d) $(P<0.01)$. Finally, D4I, D4A and Ang II were combined to treat primary VSMCs, and results showed (Fig. 6e) that in the presence of D4I, the inhibitory effect of D4A disappeared $(P<0.01)$.

\section{Effect of DRD4 activation on AT1 receptor expression in primary VSMCs of broilers}

Studies were further conducted on the regulatory effect of DRD4 on AT1 receptor in broilers. First, DRD4 in primary VSMCs treated with D4A (Fig. 7a, b) was examined. Western blotting showed that DRD4 was indeed significantly activated by D4A and inhibited by D4I in a dose-dependent manner $(P<$ 0.01) (Fig. 7a, c). The same result was also obtained in real-time PCR detection (Fig. 8a, b), indicating that D4A or D4I had activation or inhibition effects on
DRD4 at both transcriptional and translational levels $(P<0.01)$.

Further examination was performed on the expression of AT1 receptor after treatment with agonists or inhibitors of DRD4 to determine the mechanism of negative regulation of Ang II function by DRD4. The results showed (Fig. 7a, d) that expression of AT1 receptor in primary VSMCs was significantly decreased by D4A-mediated activation of DRD4 in a dosedependent manner $(P<0.01)$. The following experiment showed that the opposite direction of DRD4 affect on AT1 receptor expression in primary VSMCs of broilers was entirely attributable to DRD4 itself. When primary VSMCs were treated with different doses of D4I, AT1 receptor expression was significantly increased in a dose-dependent manner $(P<$ 0.01) (Fig. 7a, e).

The relative abundance of AT1 receptor mRNA was detected by real-time PCR. The results showed (Fig. 8c) that its expression in primary VSMCs was significantly decreased by D4A and increased by D4I in a dose-dependent manner $(P<0.01)$ (Fig. $8 \mathrm{~d})$. These results suggested that regulation of AT1 receptor by DRD4 occurs at both transcriptional and translational levels.

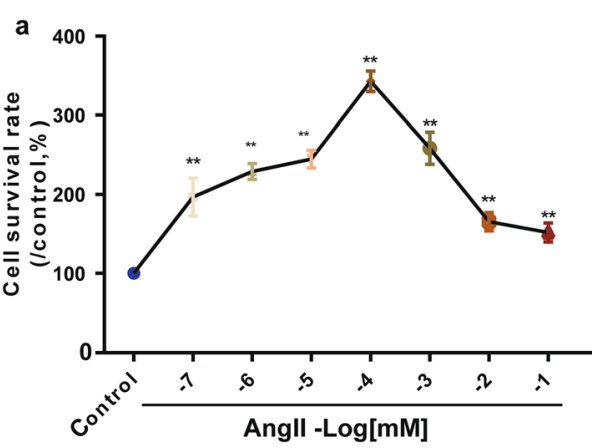

b

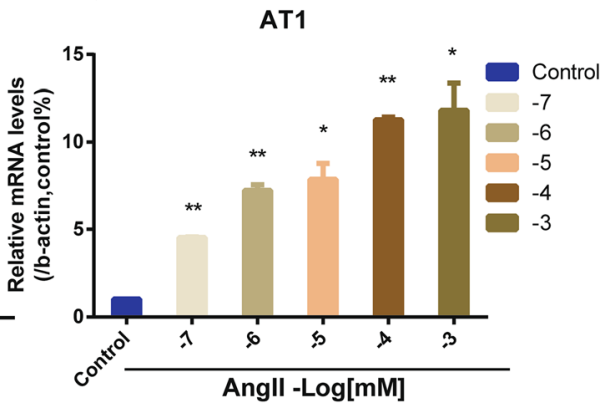

Fig. 5 Effect of Ang II on proliferation of primary vascular smooth muscle cells (VSMCs) in broilers via angiotensin II type 1 receptor (AT1). a Effect of Ang II on the proliferation of primary VSMCs. $\left(n=9,{ }^{*} P<0.01\right.$ vs. control). $\mathbf{b}$ mRNA expression of AT1 receptor stimulated by Ang $\|$ in primary VMSCs. $\left(n=6,{ }^{*} P<0.01,{ }^{*} P<0.05\right.$ vs. control) 


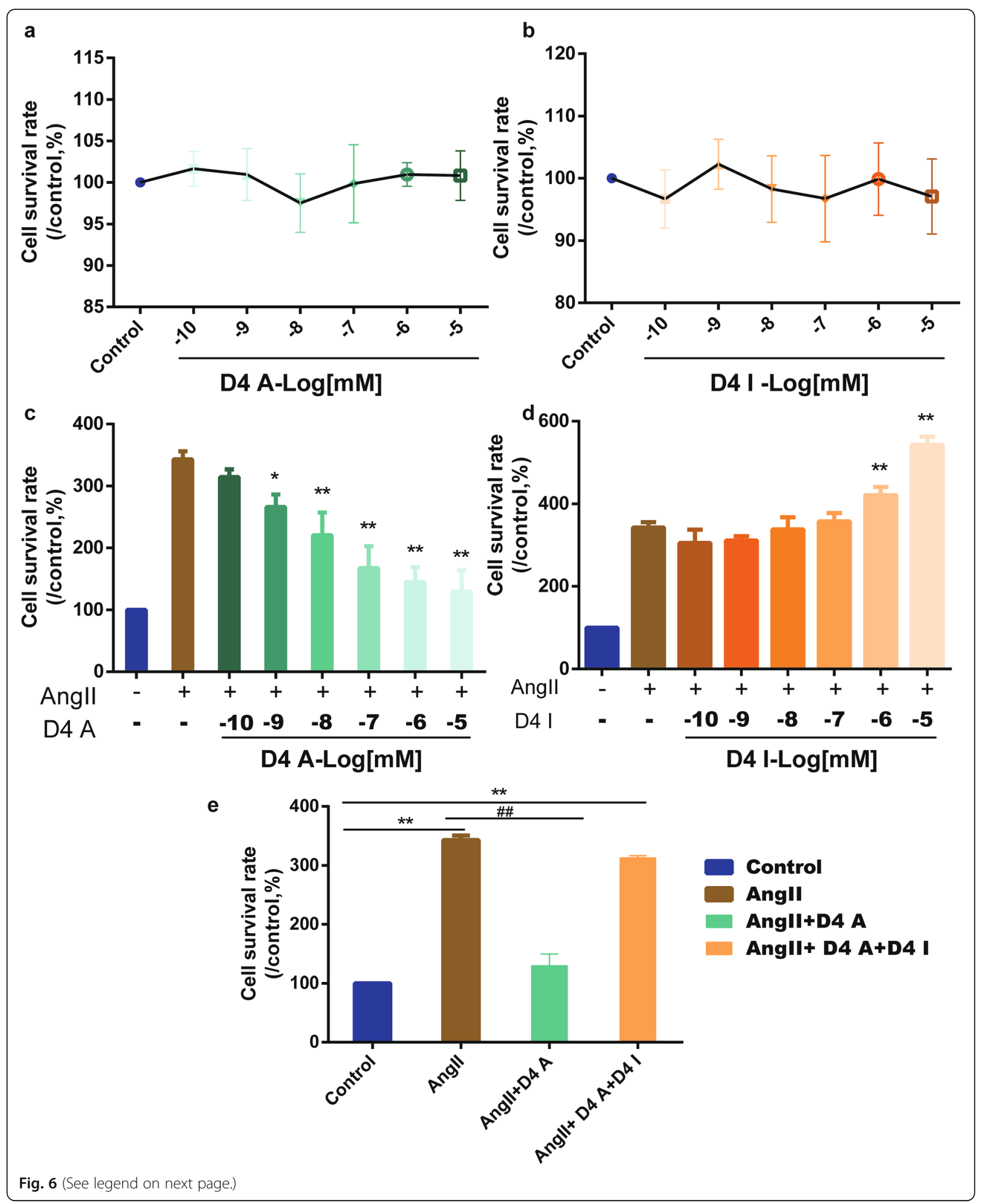


(See figure on previous page.)

Fig. 6 Effect of dopamine receptor D4 (DRD4) on Ang II-induced proliferation of primary vascular smooth muscle cells (VSMCs) in broilers. $\mathbf{a}$, $\mathbf{b}$ Effect of DRD4 agonist (D4A, HY-101384A) or DRD4 inhibitor (D4l, HY-B0965) on the proliferation of broiler primary VSMCs. c, d Effect of D4A or D4I on Ang II-mediated proliferation of broiler primary VSMCs. $\left(n=9,{ }^{* *} P<0.01{ }^{*} P<0.05\right.$ vs. control). e Specificity of DRD4 on the proliferation of broiler primary VSMCS. VSMCS were treated in four ways: control group (normal culture for $24 \mathrm{~h}$ ), Ang $\|$ group (incubated with $10^{-4} \mathrm{mM}$ of Ang $\|$ for $24 \mathrm{~h}$ ), Ang $\|+\mathrm{D} 4 \mathrm{~A}$ (incubated with $10^{-5} \mathrm{mM}$ of D4A for $2 \mathrm{~h}$ before and then with $10^{-4} \mathrm{mM}$ of Ang II for $24 \mathrm{~h}$ ), Ang II + D4A + D4I (incubated with $10^{-5} \mathrm{mM}$ of D4l for $2 \mathrm{~h}$ and then with $10^{-5} \mathrm{mM}$ of D4A for $2 \mathrm{~h}$, and finally with $10^{-4} \mathrm{mM}$ of Ang $\|$ for $\left.24 \mathrm{~h}\right)(n=9$, ** $P<0.01 \mathrm{vs}$. control, \#\# $P<0.01$ vs. Ang $\|+D 4 A)$

\section{Discussion}

Pulmonary hypertension syndrome easily occurs when broilers intake high-concentration saline for a long period of time

According to the international freshwater standard, drinking water with a salt content below $1 \mathrm{~g} / \mathrm{L}$ is categorized into the freshwater group. In many areas of China where freshwater salinization has become a problem, contents of $\mathrm{Na}^{+}$and $\mathrm{Cl}^{-}$in groundwater exceed 2500 mg/L (Yonghe 2010; Yuheng 2018; Jian 2017; Luchen 2017). Therefore, deionized water containing $2.5 \mathrm{~g} / \mathrm{L}$ $\mathrm{NaCl}$ is considered as a low salinization freshwater group, while that containing $5 \mathrm{~g} / \mathrm{L} \mathrm{NaCl}$ is considered a high salinization freshwater group. According to the test results of $\mathrm{AHI}$ and $\mathrm{HCT}$, drinking water containing $5 \mathrm{~g} /$ $\mathrm{L} \mathrm{NaCl}$ was more likely to cause PHS than drinking water containing $2.5 \mathrm{~g} / \mathrm{L} \mathrm{NaCl}$. However, the AHI and $\mathrm{HCT}$ of broilers drinking water containing $2.5 \mathrm{~g} / \mathrm{L} \mathrm{NaCl}$ were significantly higher than those of control group, and the feather state, mental state and reaction ability of broilers were all weakened compared with control group. These results indicated that content of sodium and chloride ions in drinking water of broilers exceeded 2.5 $\mathrm{g} / \mathrm{L}$ for a long period of timewould cause great damage to broiler health.

\section{Ang II is involved in broiler pulmonary hypertension syndrome induced by high-salt drinking water via its receptor}

Ang II induces mammalian hypertension, which is exacerbated by increased salt intake (Collister et al. 2013; Singh et al. 2017). In birds, continuous Ang II injection increases water intake (Singh et al. 2017), inducing increased $\mathrm{Na}^{+}$intake. According to the results of this study, long-term intake of water containing $2.5 \mathrm{~g} / \mathrm{L}$ or 5 $\mathrm{g} / \mathrm{L} \mathrm{NaCl}$ will cause abnormal proliferation of pulmonary VSMCs in broilers, and its severity is decided by $\mathrm{NaCl}$ concentration. Abnormal proliferation of VSMCs is an important factor affecting pulmonary vascular remodeling, which is a key link in causing PHS in broilers.

Participation of its receptor is required in Ang II. In mammals, Ang II can promote the growth and proliferation of cardiomyocytes, VSMCs, fibroblasts and mesangial cells through AT1 receptor (Zheng et al. 2007; Touyz et al. 2004). This research reported that an increase in Ang II content was accompanied by an increase in AT1 receptor protein expression and a decrease in DRD4 protein expression, both of which were accompanied by an increase in $\mathrm{NaCl}$ concentration in drinking water. Accordingly, we speculate that the proliferation of VSMCs in broilers induced by drinking salted water might be caused by the increase in Ang II content, which exerts a proproliferation effect through its AT1 receptor, while some negative regulation exists between DRD4 and AT1 receptor.

\section{Proliferation of primary VSMCs in broilers via AT1 receptor}

Subsequent cell experiments confirmed this speculation. The results showed that proliferation ability of VSMCs increased with Ang II concentration. According to Realtime PCR, proliferative effect of Ang II is probably achieved by promoting the expression of AT1 receptor. This may be due to the activation of certain cell growth factors by AT1 receptor. Studies have shown that Ang II could activate MAPK/ERK signaling pathway through AT1 receptor, thereby promoting proliferation of VSMCs (Chai et al. 2002; Touyz et al. 2004; Zheng et al. 2007; Zhu et al. 2005). However, when Ang II dose exceeds $10^{-4} \mathrm{mM}$, proliferation ability of VSMCs gradually weakens. Angiotensin II type 1 and angiotensin II type 2 (AT2) receptors are the main angiotensin receptors in mammals. AT1 receptor mainly affects cell proliferation and smooth muscle contraction, while AT2 receptor mainly affects cell apoptosis and smooth muscle relaxation (Williams et al. 2010). AT1 receptor is the dominant receptor under low doses of Ang II, playing a role in promoting cell proliferation. When Ang II dosage is too high, saturation of binding sites of AT1 receptor causes AT2 receptor to become dominant and brings a proapoptotic effect into play (Qiu and Ji 2014). Although $\mathrm{t}$ avian Ang II receptor is atypical and cannot be easily categorized into either of the two mammalian Ang II receptors (Chai et al. 2002; Crossley 2nd et al. 2010; Murphy et al. 1993), numerous data indicated that in addition to the cloned AT1 receptor, avians were likely to possess another type of angiotensin receptor that expresses the characteristics 

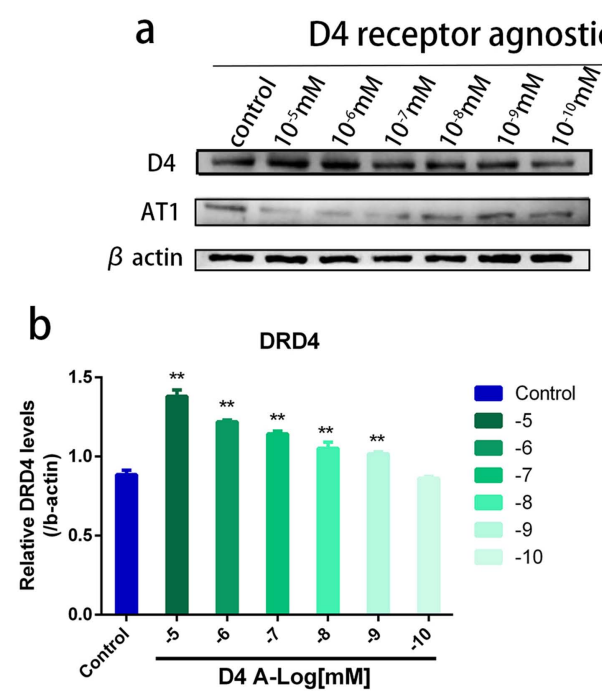

C
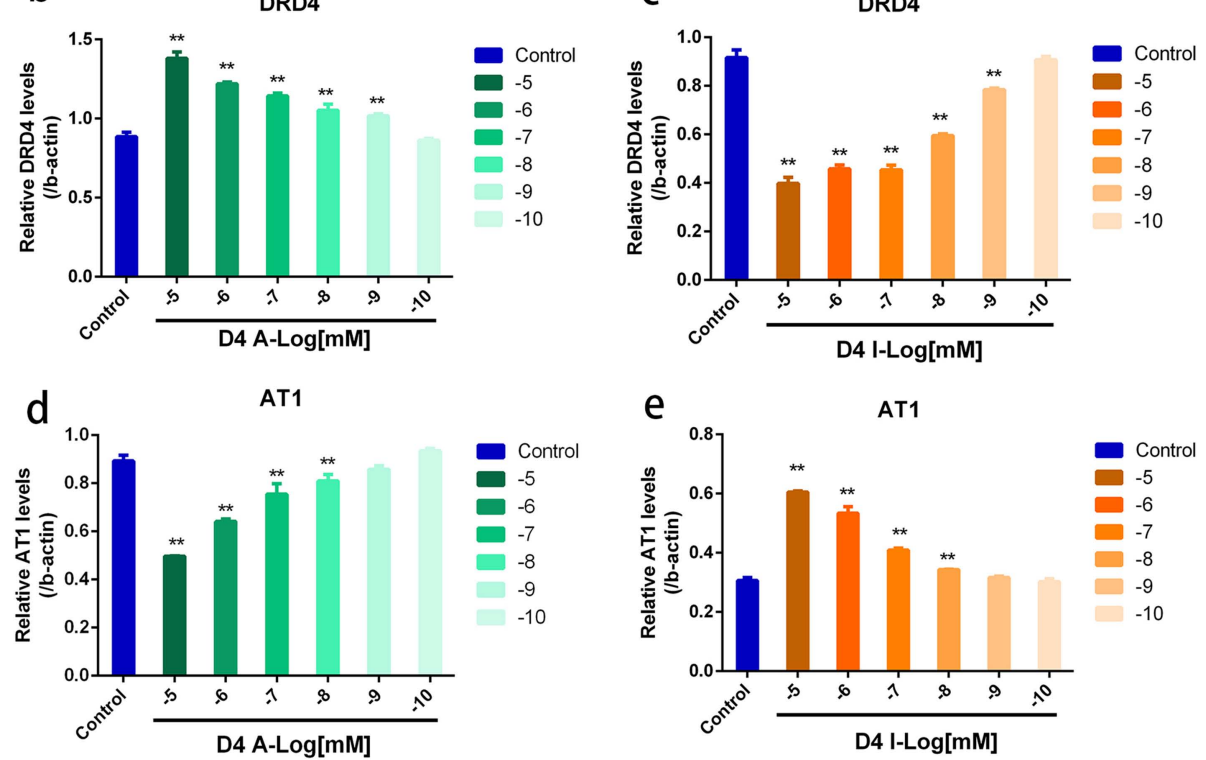

Fig. 7 Effect of dopamine receptor D4 (DRD4) on angiotensin II type 1 receptor (AT1) protein expression in primary vascular smooth muscle cells (VSMCs) of broilers. VMSCs were incubated with different doses of D4A or D4I for $24 \mathrm{~h}$. $\mathbf{a}, \mathbf{b}, \mathbf{c}$ Dose-dependent effect of D4A (HY-101384A) or D4I (HY-B0965) $\left(n=6,{ }^{* *} P<0.01\right.$ vs. control). a, d, e The dose-dependent effect of D4A or D4I $\left(n=6,{ }^{*} P<0.01\right.$ vs. control)

of mammalian AT2 receptor in many different mesenchymal tissues.

Of note, AT1 receptor expression in chicken VSMCs changes with growth and development. Angiotensin-type receptor (cAT1) cloned from chickens is present in kidneys, adrenal glands, vascular endothelium, aortic vascular smooth muscle, and aortic adventitia of embryonic chickens and chicks (2-3 weeks old). It is no longer present in aortic VSM after adulthood (14-16 weeks of age) (Nishimura et al. 2003). However, for AA broilers that are used as food, the 43-day-old slaughter time determines that cAT1 is present throughout the growth and development period from birth to sale. Studies have shown (Mueller et al. 2013) that the reduction of Ang II in embryonic chickens changed normal baroreflex function. During the development of chickens, embryos can be used as a natural model for elevated Ang II to study developmental cardiovascular functions. Therefore, 18-day-old AA broiler chicken embryos were selected as the source of primary VSMCs in this experiment.

\section{DRD4 inhibits Ang II-induced abnormal proliferation of primary VSMCs in broilers by downregulating AT1 receptor}

Previous studies have shown that DRD4 in mammals could inhibit Ang II-mediated murine VSMCs proliferation by downregulating the expression of AT1 receptors (Yu et al. 2015). However, it is not clear whether DRD4 in chickens has an inhibitory effect on it. This report showed that activation of DRD4 in primary VSMCs of broilers inhibited this process. Such inhibition can again amplify this proliferation effect. However, activating or inhibiting DRD4 alone had no significant effect. Meanwhile, even though DRD4 is activated again after being inhibited in advance, the proliferation of VSMCs mediated by Ang II could no longer be inhibited. These results confirm that DRD4 in broilers can antagonize the proliferation of VSMCs induced by Ang II.

Previous studies have successfully cloned dopamine receptor D4 (cDRD4) from chicken brain, which containing 378 amino acids with $57 \%$ homology of mouse DRD4. A series of experiments confirmed ( $\mathrm{Lv}$ et al. 

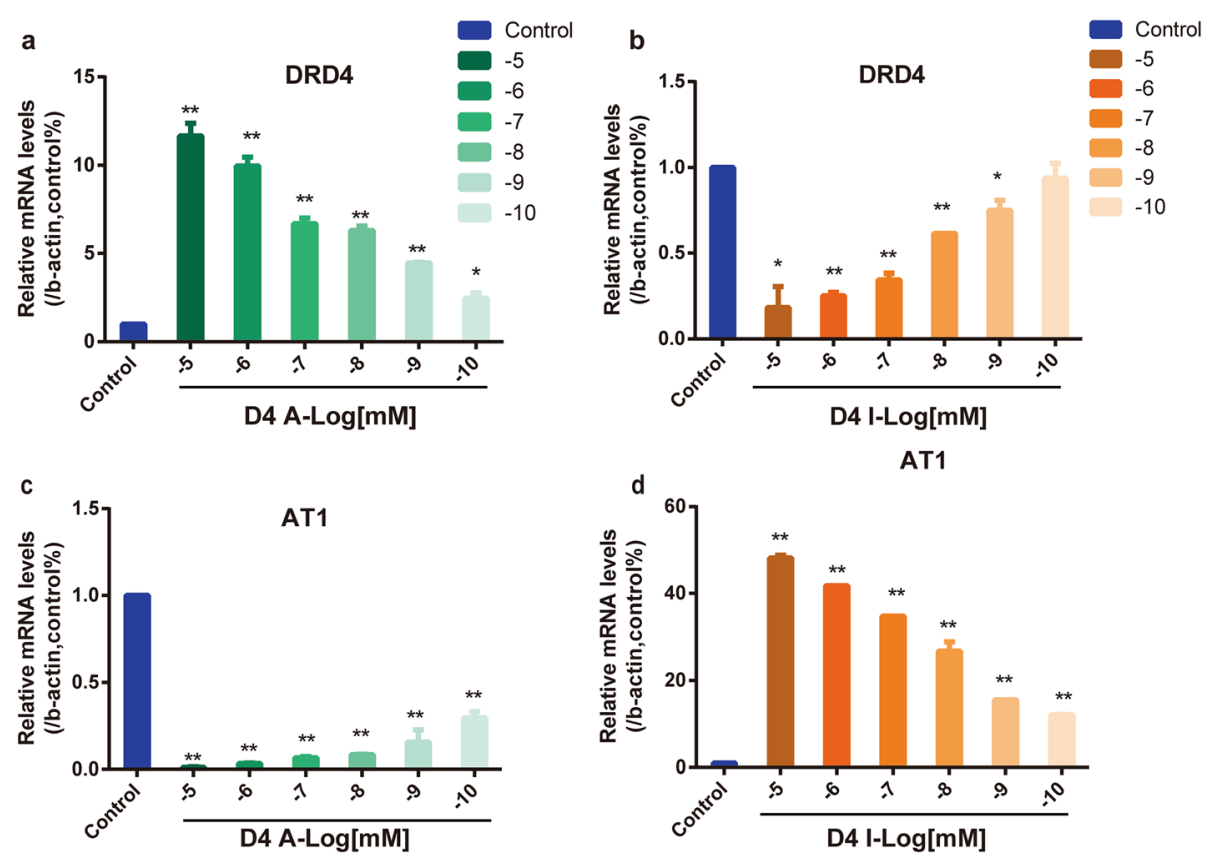

Fig. 8 Effect of dopamine receptor D4 (DRD4) on the relative abundance of angiotensin II type 1 receptor (AT1) mRNA in primary VSMCS of broilers. VMSCs were incubated with different doses of D4A or D4I for $24 \mathrm{~h}$. a, b Dose-dependent effect of D4A (HY-101384A) or D4I (HY-B0965) $\left(n=6,{ }^{* *} P<0.01,{ }^{*} P<0.05\right.$ vs. control). c, d Dose-dependent effect of D4A or D4I ( $n=6,{ }^{* *} P<0.01$ vs. control)

2018) that cDRD4 in chicken is functional in mediating the action of dopamine. However, it has not been reported to date whether DRD4 in chickens can negatively regulate AT1 receptor. Here, we reported that DRD4 in primary VSMCs of broilers can negatively regulated AT1 receptor at transcriptional and translational levels. However, molecular mechanism by which DRD4 regulates AT1 receptor has not yet been fully explained. Some studies have suggested that PKA signaling pathway was involved in DRD4's regulation AT1 receptor (Yu et al. 2015). Studies have showed that inhibitory effect of DRD4 on AT1 receptor expression in WKY cells can be blocked by calcium channel blocker nicardipine or calcium-free medium, which indicated that $\mathrm{Ca}^{2+}$ might be involved in DRD4-mediated AT1 receptor signaling pathway (Williams et al. 2010).

\section{Conclusion}

In summary, in vivo experiments mainly showed that salinized freshwater contributed to PHS in broilers with abnormal proliferation of pulmonary VSMCs due to the action of Ang II on AT1 receptor. In vitro experiments confirmed that DRD4 in broilers, by regulating AT1 receptors, could inhibit the abnormal proliferation of primary VSMCs mediated by Ang II. However, the physiological mechanism of DRD4's regulation AT1 receptor in broilers need to be further studied due to the complexity of the process.

\section{Methods \\ Materials}

DRD4 agonist (D4A, HY-101384A, MEC), DRD4 inhibitor (D4I, HY-B0965, MEC), angiotensin II (A107852, Aladdin), RIPA lysis buffer (BK504A, Biosharp), PMSF (BL507A, Biosharp), pancreatin (BL501A, Biosharp), DMEM-F12 (Gibco), fetal bovine serum (FBS-12A, Capricorn), TRIzol (G3013, Servicebio), reverse transcription kit (Wuhan, Qingke), fluorescent quantitative PCR kit (Wuhan, Qingke), polyacrylamide (BL513A, Biosharp), PVDF membrane (IPVH00010, Merck Millipore), chicken Ang II ELISA kit (MEIMIAN, MM-6022802), rabbit AGTR1 pAb antibody (A14201, ABclonal), Rabbit Anti-Dopamine DRD4 antibody (bs-1746R, bioss), PCNA antibody (Boster, BM0104), ACTB rabbit mAb (AC026, ABclonal), anti-alpha smooth muscle actin antibody (BM0002, Boster), HRP goat anti-rabbit IgG (AS014, ABclonal), HRP goat anti-mouse (KPL, 0741806), a gel instrument (Beijing, Liuyi), CCK-8 (BS350A, Biosharp), and penicillin-streptomycin (BL505A, Biosharp) were used.

\section{Experimental animal and group design}

Purchased from Yichang Zhengda Animal Husbandry Co., Ltd. Wuhan Branch, the 40 Arbor Acres (AA) broilers used in this experiment were adaptively raised in a special broiler breeding room for a week before the formal experiment. Then, they were randomly divided into four groups $(n=10)$ (Hao Yonghe 2010; Yuheng 
2018; Jian 2017; Luchen 2017): the control group (deionized water, $\mathrm{NaCl}$ at $0 \mathrm{~g} / \mathrm{L}$ ), the freshwater group (FW, deionized water $+\mathrm{NaCl}$ at $1 \mathrm{~g} / \mathrm{L}$ ), the high salinized freshwater group $1(\mathrm{H}-\mathrm{SFW}-1$, deionized water $+\mathrm{NaCl}$ at $2.5 \mathrm{~g} / \mathrm{L})$ and the high salinized freshwater group $2(\mathrm{H}-$ SFW-2, deionized water $+\mathrm{NaCl}$ at $5 \mathrm{~g} / \mathrm{L}$ ). This experiment adopted the recommendations of the National Research Council (Hongfu 1994) (Table 1), allowing each group of broilers to eat standard feed at libitum. The broilers were fed in this way for 35 days, and on the last day, all four groups were weighed, and their data were recorded. After sampling their blood, all poultry were killed through anesthesia. Then, their lungs, hearts, livers, pulmonary artery blood vessels and kidneys were extracted for preservation. The weights of organs were recorded, and tissues were refrigerated for storage at $-80^{\circ} \mathrm{C}$.

\section{PHS model measurement}

The currently accepted standard for successful PHS modeling is to measure and calculate the hematocrit $(\mathrm{HCT})$, and the ascites heart index (AHI) is calculated by dividing the weight of the right ventricle by the weight of the whole ventricle $(\mathrm{AHI}=\mathrm{RV} / \mathrm{TV})$ of broilers (Pakdel et al. 2005). When PHS model was successfully established, a light yellow liquid was observed in the abdominal cavity and pericardium. Additionally, PHS model is successful if the results AHI $(\mathrm{RV} / \mathrm{TV}) \geq 0.28$ and $\mathrm{HCT} \geq 0.36$ are positive (Cheng et al. 2021; Yang et al. 2016).

Table 1 Ingredient and nutrient composition of basal diets

\begin{tabular}{lll}
\hline $\begin{array}{l}\text { Ingredients Item (\% unless } \\
\text { noted) }\end{array}$ & $\begin{array}{l}\text { Starter (1-21 } \\
\text { days) }\end{array}$ & $\begin{array}{l}\text { Grower (22-35 } \\
\text { days) }\end{array}$ \\
\hline Corn & 55.2 & 57.7 \\
Soybean meal & 32.0 & 27.0 \\
Oil & 3.0 & 2.5 \\
Fish meal & 2.0 & 2.0 \\
Vegetable meal & 4.0 & 4.0 \\
Dicalcium phosphate & 1.5 & 1.3 \\
Calcium carbonate & 1.0 & 1.2 \\
Salt & 0.3 & 0.3 \\
Additive & 1.0 & 1.0 \\
Metabolizable energy $(\mathrm{kcal} / \mathrm{kg})$ & 2988 & 3083 \\
Crude protein & 21.52 & 19.43 \\
Lysine & 1.10 & 1.13 \\
Methionine + cysteine & 0.85 & 0.72 \\
Calcium & 1.00 & 0.90 \\
Available phosphorus & 0.50 & 0.35 \\
Vitamin E analyzed (mg/kg) & 33.20 & 33.60 \\
Selenium analyzed (mg/kg) & 0.25 & 0.24 \\
\hline
\end{tabular}

\section{Detection of Ang II in pulmonary artery smooth muscle}

As per the manufacturer's recommendation, the Chicken Ang II ELISA kit (MM-6022802, MEIMIAN) was used to measure the production of Ang II in samples of the four groups $(10 \mu \mathrm{L}, 3 \mathrm{mg} / \mu \mathrm{L}$ protein sample solution). Next, the absorbance was read at $450 \mathrm{~nm}$ on a microplate reader (SPECTROstar Nano, BMG LABTECH).

\section{Cell culture}

Embryos of 18-day AA broilers were disinfected with alcohol, and then, their hearts and lungs were exposed aseptically on a superclean bench. Afterwards, the white pulmonary blood vessels linked to heart were carefully extracted. The circular white pulmonary blood vessels were opened, and the inner wall was lightly scraped several times with a blade to remove vascular endothelial cells. Then, the white pulmonary blood vessels were fully cut for $5 \mathrm{~min}$ in a prechilled D-hanks solution, washed four times with a prechilled D-hanks solution, and finally transferred to a small sterile beaker prepared beforehand. Then, $5 \mathrm{~mL}$ of $0.12 \%$ collagenase II and pancreatin preheated at $37^{\circ} \mathrm{C}$ were added to the chopped vascular tissue at a ratio of 1:1. After continuous digestion with a magnetic stirrer for $1 \mathrm{~h}$, the digestion solution was added to an equal amount of serumcontaining DMEM-F12 medium to stop digestion. This step was repeated 5-6 times until the tissue mass was completely digested. The cells were enlarged with growth medium composed of DMEM-F12 medium containing $1 \%$ penicillin and $10 \%$ fetal bovine serum and cultured in $5 \% \mathrm{CO}_{2}\left(95 \% \mathrm{O}_{2}, 5 \% \mathrm{CO}_{2}, 37^{\circ} \mathrm{C}\right)$. After reaching $70 \%$ confluence, the VSMCs were incubated in serum-free DMEM-F12 for $12 \mathrm{~h}$ before the experiment.

\section{VSMC proliferation assay}

By observing WST-8 in the presence of 1-methoxy PMS, an electron coupling agent, the absorbance value of highly water-soluble orange-yellow product formanzan will be $450 \mathrm{~nm}$. Because the color intensity of formazan is directly proportional to the number of living cells, the percentage of cell proliferation can be calculated by the formula which included in product manual. Placed in serum-free medium for $12 \mathrm{~h}$, cells were quiescent by serum starvation. Then, they were pretreated with HY101384A or HY-B0965 for $2 \mathrm{~h}$ before stimulation with different doses of Ang II for 24h. Alternatively, they were stimulated with different doses of Ang II for $24 \mathrm{~h}$ continuously. This was followed by the addition of $10 \mu \mathrm{L}$ of CKK8 to each well, after which the incubation was resumed for an additional $2 \mathrm{~h}$ at $37^{\circ} \mathrm{C}$. Next, the microplate reader read $450 \mathrm{~nm}$ (SPECTROstar Nano, BMG $\mathrm{LABTECH}$ ). The mean \pm SEM of three repeated experiments was eventually taken as the data. 


\section{Immunohistochemistry}

VSMCs were fixed on glass slides with $4 \%$ paraformaldehyde for $15 \mathrm{~min}$ and washed with sterile PBS three times. After the slides were slightly dried, $50-100 \mu \mathrm{L}$ rupture working solution $(0.3 \%$ Triton X-100 with PBS) was added, and then, they were incubated at room temperature for $20 \mathrm{~min}$ before being washed with PBS three times for $5 \mathrm{~min}$ each. Then, 3\% BSA was added dropwise and blocked at room temperature for $30 \mathrm{~min}$. After shaking off the BSA, the primary antibody working solution was dropped (1:200 $\alpha$-SMA configured with PBS), and slides were incubated overnight in a wet box. After washing three times with PBS, the secondary antibody (HRP labeled) corresponding to the primary antibody species was added dropwise before $50 \mathrm{~min}$ of incubation. After washing three times with PBS, freshly prepared DAB chromogenic solution was added dropwise. The color development time was controlled under a microscope, and the positive color was brownyellow. The section was washed with tap water to stop color development. Nucleus was counterstained with hematoxylin for approximately 3 min before rinsing with tap water. Then, cells were differentiated with hematoxylin differentiation solution for a few seconds before rinsing with tap water. Finally, the bluing solution was used to counterstain the blue before water rinsing. The slides were sequentially put in $75 \%$ alcohol, $85 \%$ alcohol, anhydrous ethanol I, and anhydrous ethanol II for $5 \mathrm{~min}$ each for dehydration. After the slides were removed from the alcohol and dried with a blower, they were sealed with neutral balsam on a glass slide with the side containing the cells before finally being observed via an inverted microscope.

\section{Immunoblotting}

One microgram of pulmonary artery blood vessels taken from the four groups of broilers was washed with PBS, and the adventitia and intima were gently scraped clean. Blood vessels were cut by scissors as much as possible and set aside. VSMCs were treated with D4A, D4I and Ang II at a specific dose for a specific time, washed twice with PBS, and put aside for backup use. The prepared tissue samples and cell samples mentioned above were lysed on ice with freshly prepared cell lysis buffer (RIPA lysis buffer: PMSF =99:1) for $30 \mathrm{~min}$ and centrifuged at $12000 \mathrm{r} / \mathrm{min}$ for $15 \mathrm{~min}$. After collecting the supernatant, cell protein concentration was determined by the BCA method (Olson 2016; Walker 1994). Electrophoresis of proteins, transfer, immunodetection and densitometric evaluation were performed as previously described (Kashihara et al. 2017; Severin and Torres 2019; Zeng et al. 2008). For densitometry of the immunoblots, samples from treated pulmonary artery blood vessels or
VSMCs were run on each gel with corresponding control samples and normalized to $\beta$-actin.

\section{RT-PCR and real-time fluorescence quantitative PCR}

TRIzol was used to separate total RNA from VSMCs. Total RNA (2000 pg) was used to synthesize cDNA, which was used as a template for the amplification of AT1, DRD4 and $\beta$-actin (housekeeping gene). The specific primers for the above genes were designed by Primer-BLAST from the National Center for Biotechnology Information (NCBI). AT1 receptor primers were $5^{\prime}$ CACGAATCCGACGTACCATG-3' (forward) and 5'AACCTAGCCCAACCCTCAGT-3' (reverse). DRD4 primers were 5' -TGCTATCAGTGTGGATCGGTTT-3' (forward) and 5'-CAGCAAAGGCGAATATCCACG-3' (reverse). $\beta$-actin receptor primers were 5 '-GCCATCTT TCTTGGGTATGGAG-3' (forward) and $5^{\prime}$-TGGTAC ACCAGACAGCACT-3' (reverse). Amplification was carried out under the following conditions: first, the temperature was kept at $95^{\circ} \mathrm{C}$ for $1 \mathrm{~min}$; second, denaturation was performed at $95^{\circ} \mathrm{C}$ for 40 cycles for $10 \mathrm{~s}$ each; third, a two-step method was performed to anneal and extend at $60^{\circ} \mathrm{C}$ for $30 \mathrm{~s}$; and finally, a dissolution curve was added according to the instrument model. qPCR was performed on a LightCycler $96^{\circ}$ instrument (Roche, Switzerland). The $\Delta \Delta \mathrm{Ct}$ method was used to normalize and analyze data.

\section{Statistical analysis}

The data reflect the mean \pm SEM from at least three independent experiments. Data were analyzed by Student's t-tests for paired samples or by ANOVA tests followed by a post hoc Newman-Keuls test for comparing multiple treatments. ImageJ program was used to quantify the expression level of each protein, normalized by the normalization of intracellular $\beta$-actin, and then expressed as a relative fold increase compared to each control without drug treatment. $P$ values of under 0.05 were considered statistically significant.

\begin{abstract}
Abbreviations
VSMCs: Vascular smooth muscle cells; VMS: Vascular smooth muscle; SM: Smooth muscle; PHS: Pulmonary hypertension syndrome; Ang II: Angiotensin II; AT1 : Angiotensin II type 1; AT2: Angiotensin II type 2; DRD4 : Dopamine receptor D4; D4A: D4 receptor agonists; D4I: D4 receptor inhibitors; RAS: Renin-angiotensin system; PDGF: Platelet derived growth factor; AA: Arbor Acres; FW: Freshwater group; H-SFW: High salinized freshwater group; HCT: Hematocrit; AHI: Ascites heart index; a-SMA: Antialpha smooth muscle actin antibody; PCNA: Proliferating cell nuclear antigen
\end{abstract}

\section{Acknowledgments}

We thank Mr. Jiang Xiaobo of ABclonal Company for providing us with antibody consulting services; the Qingke Company for providing us with primer synthesis services; Mr. Zhu Hui and Yang Hai for providing us with high-quality experimental consumables; Mr. Wu Yanjin for polishing the language of this article; and Professor Hu Changmin from Huazhong Agricultural University for lending us his instrument. Thank you to every author for all your efforts on this article. The acknowledgement list was approved by all the authors. 


\section{Compliance with ethical standards}

All experiments were performed with the approval of the Institutional Animal Welfare and Research Ethics Committee of Huazhong Agricultural University Wuhan, China.

\section{Authors' contributions}

X.Y., Y.F. and L.W. conceived and designed the experiments; Y.F., L.W., L.J., A.L. and J.Z. contributed to sample collection and reagent preparation; X.Y. and X.P. wrote the manuscript; H.L., Y.F. and L.W. provided technical guidance; D.Z. provided experimental funding; and H.Z. provided technical guidance. All the authors were involved in discussing the contents of the manuscript and agreed upon publication.

\section{Funding}

This research was funded by the Fundamental Research Funds for the Central Universities (Grant No. 2662020DKPY013), the National Natural Science Foundation of China (Grant No. 31972748) and the Huazhong Agricultural University 2020 College Student Science and Technology Innovation Fund (SRF).

\section{Availability of data and materials}

Not applicable.

\section{Declarations}

\section{Ethics approval and consent to participate}

The experimental protocol was established according to the Experimental Animal Center of Huazhong Agricultural University.

\section{Consent for publication}

Not applicable.

\section{Competing interests}

There were no conflicts of interest.

Received: 11 May 2021 Accepted: 5 July 2021

Published online: 11 August 2021

\section{References}

Banday, A.A., and M.F. Lokhandwala. 2008. Dopamine receptors and hypertension. Current Hypertension Reports 10 (4): 268-275. https://doi.org/1 $0.1007 /$ s11906-008-0051-9.

Bek, M.J., X. Wang, L.D. Asico, J.E. Jones, S. Zheng, X. Li, G.M. Eisner, D.K. Grandy, R. M. Carey, P. Soares-da-Silva, et al. 2006. Angiotensin-Il type 1 receptormediated hypertension in D4 dopamine receptor-deficient mice. Hypertension 47 (2): 288-295. https://doi.org/10.1161/01.Hyp.0000198427.9622 5.36 .

Chai, S.B., D.F. Bu, L.J. Tong, and C.S. Tang. 2002. Change of mitogen-activated protein kinase phosphatase-1 in heart and aorta of SHR and its effect on proliferation of vascular smooth muscle cells stimulated by angiotensin II. Zhongguo Ying Yong Sheng Li Xue Za Zhi 18 (1): 55-58. https://doi.org/10.134 59/j.cnki.cjap.2002.01.019.

Cheng, S., X. Liu, P. Liu, G. Li, X. Guo, G. Hu, L. Li, C. Wu, Z. Xu, Q. Ping Zhou, et al, 2021. Dysregulated expression of mRNA and SNP in pulmonary artery remodeling in ascites syndrome in broilers. Poultry Science 100 (3): 100877. https://doi.org/10.1016/j.ps.2020.11.054.

Collister, J.P., M.K. Olson, D.B. Nahey, A.A. Vieira, and J.W. Osborn. 2013. OVLT lesion decreases basal arterial pressure and the chronic hypertensive response to Angll in rats on a high-salt diet. Physiological Reports 1 (5): e00128. https://doi.org/10.1002/phy2.128.

Crossley, D.A., 2nd, S.S. Jonker, J.W. Hicks, and K.L. Thornburg. 2010. Maturation of the angiotensin II cardiovascular response in the embryonic White Leghorn chicken (Gallus gallus). Journal of Comparative Physiology. B 180 (7): 10571065. https://doi.org/10.1007/s00360-010-0473-y.

Delaney, J., R. Chiarello, D. Villar, U. Kandalam, A.M. Castejon, and M.A. Clark. 2008. Regulation of c-fos, c-jun and c-myc gene expression by angiotensin II in primary cultured rat astrocytes: role of ERK1/2 MAP kinases. Neurochemical Research 33 (3): 545-550. https://doi.org/10.1007/s11064-007-9474-y.

Harris, R.C., and M.Z. Zhang. 2012. Dopamine, the kidney, and hypertension. Current Hypertension Reports 14 (2): 138-143. https://doi.org/10.1007/s11906012-0253-z.
Hassanpour, H., S. Bahadoran, F. Neidaripour, N. Ehsanifar, I. Tavasolifar, and S. Madreseh. 2019. Brain renin-angiotensin system in broiler chickens with coldinduced pulmonary hypertension. British Poultry Science 60 (5): 499-505. https://doi.org/10.1080/00071668.2019.1632415.

Horita, S., G. Seki, H. Yamada, M. Suzuki, K. Koike, and T. Fujita. 2013. Roles of renal proximal tubule transport in the pathogenesis of hypertension. Current Hypertension Reviews 9 (2): 148-155. https://doi.org/10.2174/15734021113 099990009.

Ibrahim, M.M. 2006. RAS inhibition in hypertension. Journal of Human Hypertension 20 (2): 101-108. https://doi.org/10.1038/sj.jhh.1001960.

Jian, Wan. 2017. A study on the moisture content migration and characteristics of forsi heaving of saline soil in the western of Jilin province. (Master\&apos's Degree Dissertation), Changchun Institute of Technology, Available from Cnki. https://kns.cnki.net/KCMS/detail/detail.aspx?dbname=CMFD201701 \&filename $=1017021654$.nh

Julian, R.J. 1993. Ascites in poultry. Avian Pathology 22 (3): 419-454. https://doi. org/10.1080/03079459308418934.

Julian, R.J., L.J. Caston, and S. Leeson. 1992. The effect of dietary sodium on right ventricular failure-induced ascites, gain and fat deposition in meat-type chickens. Canadian Journal of Veterinary Research 56 (3): 214-219 https:// pubmed.ncbi.nlm.nih.gov/1423057/.

Kashihara, T., T. Nakada, K. Kojima, T. Takeshita, and M. Yamada. 2017. Angiotensin II activates $\mathrm{Ca}(\mathrm{V}) 1.2 \mathrm{Ca}(2+)$ channels through $\beta$-arrestin2 and casein kinase 2 in mouse immature cardiomyocytes. The Journal of Physiology 595 (13): 4207-4225. https://doi.org/10.1113/jp273883.

Kempf, H., J.M. le Moullec, P. Corvol, and J.M. Gasc. 1996. Molecular cloning, expression and tissue distribution of a chicken angiotensin II receptor. FEBS Letters 399 (3): 198-202. https://doi.org/10.1016/s0014-5793(96)01264-1.

Luchen, Wang. (2017) Analysis hydrochemical characteristics and fomation machanism of shallow groundwater in North Ordos Basin (Master\&apos's Degree Dissertation), Jilin University, Available from Cnki. https://kns.cnki.net/ KCMS/detail/detail.aspx?dbname $=$ CMFD201702\&filename $=1017156477$.nh

Luo, H., X. Wang, C. Chen, J. Wang, X. Zou, C. Li, Z. Xu, X. Yang, W. Shi, and C. Zeng. 2015. Oxidative stress causes imbalance of renal renin angiotensin system (RAS) components and hypertension in obese Zucker rats. Journal of the American Heart Association 4 (2). https://doi.org/10.1161/jaha.114.001559.

Lv, C., C. Mo, H. Liu, C. Wu, Z. Li, J. Li, and Y. Wang. 2018. Dopamine D2-like receptors (DRD2 and DRD4) in chickens: Tissue distribution, functional analysis, and their involvement in dopamine inhibition of pituitary prolactin expression. Gene 651: 33-43. https://doi.org/10.1016/j.gene.2018.01.087.

Mirsalimi, S.M., P.J. O'Brien, and R.J. Julian. 1993. Blood volume increase in saltinduced pulmonary hypertension, heart failure and ascites in broiler and White Leghorn chickens. Canadian Journal of Veterinary Research 57 (2): 110113 https://pubmed.ncbi.nlm.nih.gov/8490804/.

Mueller, C.A., W.W. Burggren, and D.A. Crossley 2nd. 2013. ANG II and baroreflex control of heart rate in embryonic chickens (Gallus gallus domesticus). American Journal of Physiology. Regulatory, Integrative and Comparative Physiology 305 (8): R855-R863. https://doi.org/10.1152/ajpregu.00298.2013.

Murphy, TJ., Y. Nakamura, K. Takeuchi, and R.W. Alexander. 1993. A cloned angiotensin receptor isoform from the turkey adrenal gland is pharmacologically distinct from mammalian angiotensin receptors. Molecular Pharmacology 44 (1): 1-7.

Nishimura, H., Y. Yang, C. Hubert, J.M. Gasc, K. Ruijtenbeek, J. De Mey, H.A. Boudier, and P. Corvol. 2003. Maturation-dependent changes of angiotensin receptor expression in fowl. American Journal of Physiology. Regulatory, Integrative and Comparative Physiology 285 (1): R231-R242. https://doi.org/1 0.1152/ajpregu.00481.2002.

Olson, B. 2016. Assays for Determination of Protein Concentration. Current Protocols in Pharmacology 73 (1): A.3a.1-a.3a.32. https://doi.org/10.1002/cpph.3.

Pakdel, A., P. Bijma, B.J. Ducro, and H. Bovenhuis. 2005. Selection strategies for body weight and reduced ascites susceptibility in broilers. Poultry Science 84 (4): 528-535. https://doi.org/10.1093/ps/84.4.528.

Qiu, G., and Z. Ji. 2014. Angll-induced glomerular mesangial cell proliferation inhibited by losartan via changes in intracellular calcium ion concentration. Clinical and Experimental Medicine 14 (2): 169-176. https://doi.org/10.1007/s1 0238-013-0232-y.

Reiss, K., J.M. Capasso, H.E. Huang, L.G. Meggs, P. Li, and P. Anversa. 1993. ANG II receptors, c-myc, and c-jun in myocytes after myocardial infarction and ventricular failure. The American Journal of Physiology 264 (3 Pt 2): H760H769. https://doi.org/10.1152/ajpheart.1993.264.3.H760.

Severin, M.J., and A.M. Torres. 2019. Time course effects of methotrexate on renal handling of water and electrolytes in rats. Role of aquaporin-2 and Na-K-2Cl- 
cotransporter. Toxicology Letters 311: 27-36. https://doi.org/10.1016/j.toxlet.2 019.04.018.

Singh, P., A. Castillo, M.T. Islam, and D.S.A. Majid. 2017. Evidence for Prohypertensive, Proinflammatory Effect of Interleukin-10 During Chronic High Salt Intake in the Condition of Elevated Angiotensin II Level. Hypertension 70 (4): 839-845. https:// doi.org/10.1161/hypertensionaha.117.09401.

Touyz, R.M., G. Yao, E. Viel, F. Amiri, and E.L. Schiffrin. 2004. Angiotensin II and endothelin-1 regulate MAP kinases through different redox-dependent mechanisms in human vascular smooth muscle cells. Journal of Hypertension 22 (6): 1141-1149. https://doi.org/10.1097/00004872-200406000-00015.

Walker, J.M. 1994. The bicinchoninic acid (BCA) assay for protein quantitation. Methods in Molecular Biology 32: 5-8. https://doi.org/10.1385/0-89603-268-x:5.

Wang, Z., P.J. Rao, S.D. Shillcutt, and W.H. Newman. 2005. Angiotensin II induces proliferation of human cerebral artery smooth muscle cells through a basic fibroblast growth factor (bFGF) dependent mechanism. Neuroscience Letters 373 (1): 38-41. https://doi.org/10.1016/j.neulet.2004.09.068.

Wideman, R.F., Jr., and Y.K. Kirby. 1995. A pulmonary artery clamp model for inducing pulmonary hypertension syndrome (ascites) in broilers. Poultry Science 74 (5): 805-812. https://doi.org/10.3382/ps.0740805.

Williams, P.J., H.D. Mistry, B.A. Innes, J.N. Bulmer, and F. Broughton Pipkin. 2010. Expression of AT1R, AT2R and AT4R and their roles in extravillous trophoblast invasion in the human. Placenta 31 (5): 448-455. https://doi.org/10.1016/j.pla centa.2010.02.014.

Yang, F., H. Cao, Q. Xiao, X. Guo, Y. Zhuang, C. Zhang, T. Wang, H. Lin, Y. Song, G. $\mathrm{Hu}$, and P. Liu. 2016. Transcriptome Analysis and Gene Identification in the Pulmonary Artery of Broilers with Ascites Syndrome. PLoS One 11 (6): e0156045. https://doi.org/10.1371/journal.pone.0156045.

Ying, Li, Zeng Jianying, Han Qianbiao, Tang Zhaoxin, Guo Jianying, and Pan Jiaqiang. 2011. The effect of Setotonin on the proliferation and apoptosis of broiler pulmonary artery smooth muscle cells. Chinese Journal of Veterinary Medicine 31 (08): 1205-1207. https://doi.org/10.16303/j.cnki.1005-4545.2011.08.029.

Yonghe, Hao. (2010) Study on chemistry characteristic of groundwater and formation machanism in Akesu area. (Master\&apos;s Degree Dissertation), Xinjiang Tarim University, Available from Cnki. https://kns.cnki.net/KCMS/deta il/detail.aspx?dbname $=$ CMFD2010\&filename $=2010107945$. nh

Yu, C., J. Chen, W. Guan, Y. Han, W.E. Wang, X. Wang, H. Wang, P.A. Jose, and C. Zeng. 2015. Activation of the D4 dopamine receptor attenuates proliferation and migration of vascular smooth muscle cells through downregulation of AT1a receptor expression. Hypertension Research 38 (9): 588-596. https://doi. org/10.1038/hr.2015.48

Yu, C., Z. Wang, Y. Han, Y. Liu, W.E. Wang, C. Chen, H. Wang, P.A. Jose, and C. Zeng. 2014. Dopamine $D_{4}$ receptors inhibit proliferation and migration of vascular smooth muscle cells induced by insulin via down-regulation of insulin receptor expression. Cardiovascular Diabetology 13 (1): 97. https://doi. org/10.1186/1475-2840-13-97.

Yuheng, Lin. (2018) Water-rock interactions of shallow saline groundwater downward leakage to deep-seated fresh groundwater. (Master\&apos;s Degree Dissertation), Tianjin University of Science and Technology, Available from Cnki. https://kns.cnki.net/KCMS/detail/detail.aspx?dbname=CMFD201901 \&filename $=1019036153 . \mathrm{nh}$

Zeng, C., I. Armando, Y. Luo, G.M. Eisner, R.A. Felder, and P.A. Jose. 2008. Dysregulation of dopamine-dependent mechanisms as a determinant of hypertension: studies in dopamine receptor knockout mice. American Journal of Physiology. Heart and Circulatory Physiology 294 (2): H551-H569. https://doi. org/10.1152/ajpheart.01036.2007.

Zhang, J., X. Feng, L. Zhao, W. Wang, M. Gao, B. Wu, and J. Qiao. 2013. Expression of hypoxia-inducible factor 1a mRNA in hearts and lungs of broiler chickens with ascites syndrome induced by excess salt in drinking water. Poultry Science 92 (8): 2044-2052. https://doi.org/10.3382/ps.2013-03097.

Zheng, S., Z. Qian, N. Wen, and L. Xi. 2007. Crocetin suppresses angiotensin II-induced vascular smooth-muscle cell proliferation through inhibition of ERK1/2 activation and cell-cycle progression. Journal of Cardiovascular Pharmacology 50 (5): 519-525. https://doi.org/10.1097/FJC.0b013e31813c114e.
Zhu, J.H., Z. Liu, Z.Y. Huang, and S. Li. 2005. Effects of angiotensin II on extracellular signal-regulated protein kinases signaling pathway in cultured vascular smooth muscle cells from Wistar-Kyoto rats and spontaneously hypertensive rats. Sheng Li Xue Bao 57 (5): 587-592. https://doi.org/10.13294/ j.aps.2005.05.007.

Zhang, F. U.S. NRC Poultry Nutrient Requirements (1994 Edition). China Feed .02(1995):36-38. CNKI:SUN:SLGZ.0.1995-02-018.

\section{Publisher's Note}

Springer Nature remains neutral with regard to jurisdictional claims in published maps and institutional affiliations.

\section{Ready to submit your research? Choose BMC and benefit from:}

- fast, convenient online submission

- thorough peer review by experienced researchers in your field

- rapid publication on acceptance

- support for research data, including large and complex data types

- gold Open Access which fosters wider collaboration and increased citations

- maximum visibility for your research: over $100 \mathrm{M}$ website views per year

At BMC, research is always in progress.

Learn more biomedcentral.com/submissions 